\title{
Study of C-Reactive Protein Level in Patients with Stable COPD and in Acute Exacerbations
}

\author{
HAMDY M. ZOAIR, M.D.*; MOUSTAFA A. ZEDAN, M.D.*; MAHMOUD A. ARAFA, M.D.*; \\ MOHAMED R. MORSY, M.D.** and AMR A. AL-MOOGY, M.Sc.* \\ The Departments of Chest Diseases* and Clinical Pathology**, Faculty of Medicine, Al-Azhar University, Egypt
}

\begin{abstract}
Background: C-Reactive Protein (CRP) is an inflammatory mediator that is increased in patients with Chronic Obstructive Pulmonary Disease (COPD) and can be used as diagnostic and prognostic adjuvant to assess the severity of disease.

Aim of Study: This study was the difference in the CRP level between stable COPD and AECOPD patients.

Subjects and Methods: Sixty COPD patients (30 with stable COPD and 30 with AECOPD) were included in this study and results were compared to those of 10 healthy age/sexmatched controls. Clinical history was taken and full clinical examination was done to assess the patients' conditions and rule out any co-morbidities that could be associated with increased CRP level. Blood samples were drawn to measure the CRP level, ABG and TLC. Pulmonary function test was also done.

Results: CRP level was significantly higher in COPD patients compared to healthy controls ( $p$-value $<0.0001)$. It was also significantly higher in AECOPD patients compared to patients with stable COPD ( $p$-value $<0.0001)$.

Conclusion: CRP level is generally increased in COPD patients, being significantly higher in the AECOPD patients than the stable ones, and thus can be used as a prognostic marker to assess the severity of the disease.
\end{abstract}

Key Words: $C O P D-C R P$.

\section{Introduction}

CHRONIC Obstructive Pulmonary (COPD) has several clinical and pathologic entities, primarily emphysema and chronic bronchitis. Evidence of airflow obstruction is chronic, progressive and almost fixed [1] . CRP is a member of class of defense molecules called acute phase proteins. The levels of acute phase proteins rise rapidly during infection, after injury and in inflammatory condi-

Correspondence to: Dr. Amr A. Al-Moogy, The Department of Chest Diseases, Agouza Police Hospital, Cairo, Egypt tions [2] . CRP is one of the inflammatory markers which is increasingly evaluated in COPD patients [3] . It is increased in patients with Acute Exacerbations of COPD (AECOPD) and can be used as a prognostic marker to assess the severity of the disease [4].

\section{Subjects and Methods}

This study was performed on seventy subjects: Sixty COPD patients (55 males and 5 females) and ten age/sex matched healthy controls ( 9 males and 1 female). COPD patients were admitted to the Chest Department at Agouza Police Hospital in the period between June 2016 to August 2017. Thirty patients with stable COPD (28 males and 2 females) and 30 patients with AECOPD (27 males and 3 females) were assessed.

\section{All patients were subjected to the following:}

Clinical history (smoking, symptoms: Cough, expectoration, dyspnea and wheezes and other comorbidities that may raise the CRP level e.g. ischemic heart diseases, hypertension and diabetes mellitus).

General and local clinical examination.

Radiological examination via a plain X-ray (postero-anterior view).

Pulmonary function tests were done, namely FEV 1 and FEV $1 /$ FVC.

Blood samples for Arterial Blood Gases (ABG), CRP level and TLC.

\section{Inclusion criteria include:}

Pulmonary functional tests proving the presence of airway obstruction, namely $\mathrm{FEV}_{1} / \mathrm{FVC}<70 \%$, 
that is irreversible $(<10 \%$ improvement after use of bronchodilator).

For the stable COPD group: No history of exacerbation for the three months prior to their inclusion in the study.

For the AECOPD group: Symptoms of exacerbation (increased dyspnea, increased amount or purulence of sputum and increased cough) with or without signs of right sided heart failure.

\section{Exclusion criteria include:}

Any disease identified by history and clinical examination that may elevate the CRP level as: Pneumonia, bronchial asthma, any cardiopulmonary disease, diabetes mellitus, malignancy, connective tissue disorders or chronic liver disease.

Patient on Non-Steroidal Anti-Inflammatory Drugs (NSAIDS) as these drugs may help to reduce the inflammation, thus reducing CRP level.

\section{Statistical analysis:}

Statistical analysis of the present study was conducted, using the mean, standard deviation, analysis of variance [ANOVA] test, chi-square test and independent sample $t$-test by SPSSV.

\section{Results}

Table (1): Age and sex distribution among cases.

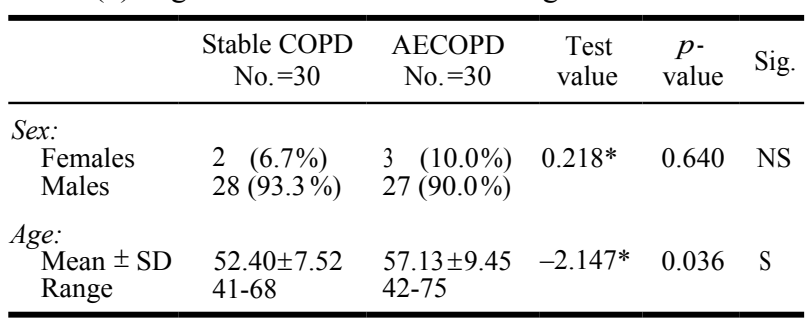

Table (2): Clinical presentation of cases.

\begin{tabular}{|c|c|c|c|c|c|c|c|}
\hline & \multicolumn{2}{|c|}{ Stable COPD } & \multicolumn{2}{|c|}{ AECOPD } & \multirow{2}{*}{$\begin{array}{c}\text { Test } \\
\text { value }\end{array}$} & \multirow{2}{*}{$\begin{array}{c}p- \\
\text { value }\end{array}$} & \multirow{2}{*}{ Sig. } \\
\hline & No. & $\%$ & No. & $\%$ & & & \\
\hline \multicolumn{8}{|l|}{ Smoking: } \\
\hline Negative & 3 & 10.0 & 0 & 0.0 & 3.158 & 0.076 & NS \\
\hline Positive & 27 & 90.0 & 30 & 100.0 & & & \\
\hline \multicolumn{8}{|l|}{ Cough: } \\
\hline Negative & 0 & 0.0 & 0 & 0.0 & NA & NA & NA \\
\hline Positive & 30 & 100.0 & 30 & 100.0 & & & \\
\hline \multicolumn{8}{|l|}{ Dyspnea: } \\
\hline No & 5 & 16.7 & 0 & 0.0 & 60.000 & 0.000 & HS \\
\hline Mild & 25 & 83.3 & 0 & 0.0 & & & \\
\hline Moderate & 0 & 0.0 & 20 & 66.7 & & & \\
\hline Severe & 0 & 0.0 & 10 & 33.3 & & & \\
\hline \multicolumn{8}{|l|}{ Wheezes: } \\
\hline Negative & 18 & 60.0 & 13 & 43.3 & 1.669 & 0.196 & NS \\
\hline Positive & 12 & 40.0 & 17 & 56.7 & & & \\
\hline \multicolumn{8}{|l|}{ Cyanosis: } \\
\hline Negative & 27 & 90.0 & 5 & 16.7 & 32.411 & 0.000 & HS \\
\hline Positive & 3 & 10.0 & 25 & 83.3 & & & \\
\hline
\end{tabular}

Table (3): Pulmonary function in stable COPD and AECOPD.

\begin{tabular}{llllll}
\hline & $\begin{array}{c}\text { Stable COPD } \\
\text { No. }=30\end{array}$ & $\begin{array}{c}\text { AECOPD } \\
\text { No. }=30\end{array}$ & $\begin{array}{c}\text { Test } \\
\text { value }\end{array}$ & $\begin{array}{c}p \text { - } \\
\text { value. }\end{array}$ & Sig. \\
\hline Range & $6.5-14$ & $8-17$ & & & \\
FEVI/FVC: & & & & & \\
$\quad$ Mean \pm SD & $65.57 \pm 3.01$ & $50.57 \pm 6.71$ & 11.163 & 0.000 & HS \\
$\quad$ Range & $60-69$ & $36-59$ & & & \\
FEV1\%: & & & & & \\
$\quad$ Mean \pm SD & $58.13 \pm 16.37$ & $45.77 \pm 23.93$ & 2.337 & 0.023 & $\mathrm{~S}$ \\
$\quad$ Range & $22-91$ & $16-94$ & & & \\
\hline
\end{tabular}

Table (4): Arterial blood gases in stable COPD and AECOPD.

\begin{tabular}{|c|c|c|c|c|c|}
\hline & $\begin{array}{c}\text { Stable COPD } \\
\text { No. }=30\end{array}$ & $\begin{array}{c}\text { AECOPD } \\
\text { No. }=30\end{array}$ & $\begin{array}{c}\text { Test } \\
\text { value }\end{array}$ & $\begin{array}{c}p- \\
\text { value }\end{array}$ & Sig. \\
\hline$P H:$ & & & & & \\
\hline $\begin{array}{l}\text { Mean } \pm \text { SD } \\
\text { Range }\end{array}$ & $7.39 \pm 0.03$ & $7.27 \pm 0.11$ & 5.724 & 0.000 & HS \\
\hline PO2: & & & & & \\
\hline $\begin{array}{l}\text { Mean } \pm \text { SD } \\
\text { Range }\end{array}$ & $\begin{array}{l}82.57 \pm 7.83 \\
70-95\end{array}$ & $\begin{array}{l}52.83 \pm 15.47 \\
30-80\end{array}$ & 9.393 & 0.000 & HS \\
\hline $\begin{array}{l}P C O 2: \\
\text { Mean } \pm \text { SD } \\
\text { Range }\end{array}$ & $\begin{array}{l}41.00 \pm 3.07 \\
35-45\end{array}$ & $\begin{array}{l}50.73 \pm 6.05 \\
40-62\end{array}$ & -7.855 & 0.000 & HS \\
\hline $\begin{array}{l}\mathrm{SO} 2: \\
\quad \text { Mean } \pm \text { SD } \\
\text { Range }\end{array}$ & $\begin{array}{l}92.33 \pm 1.77 \\
89-95\end{array}$ & $\begin{array}{l}84.93 \pm 2.82 \\
80-91\end{array}$ & 12.191 & 0.000 & HS \\
\hline
\end{tabular}

Table (5): CRP level in control, stable COPD and AECOPD.

\begin{tabular}{|c|c|c|c|c|c|c|}
\hline CRP level & $\begin{array}{c}\text { Control } \\
\text { Volunteers } \\
\text { No. }=10\end{array}$ & $\begin{array}{c}\text { Stable } \\
\text { COPD } \\
\text { No. }=30\end{array}$ & $\begin{array}{c}\text { AECOPD } \\
\text { No. }=30\end{array}$ & $\begin{array}{l}\text { Test } \\
\text { value• }\end{array}$ & $\begin{array}{c}p- \\
\text { value }\end{array}$ & Sig. \\
\hline Mean $\pm \mathrm{SD}$ & $\begin{array}{l}6.10 \pm \\
2.60\end{array}$ & $\begin{array}{l}52.47 \pm \\
19.86\end{array}$ & $\begin{array}{l}107.63 \pm \\
16.31\end{array}$ & 161.34 & 0.000 & HS \\
\hline Range & $2-10$ & $20-90$ & $74-140$ & & & \\
\hline
\end{tabular}

\section{Discussion}

Chronic obstructive pulmonary disease (COPD), a common preventable and treatable disease, is characterized by persistent airflow limitation that is usually progressive and associated with an enhanced chronic inflammatory response in the airways and the lung to noxious particles or gases. Exacerbations and comorbidities contribute to the overall severity in individual patients [5].

The chronic airflow limitation that characterizes COPD is caused by a mixture of small airway disease (e.g. obstructive bronchiolitis) and parenchymal destruction (emphysema), the relative contributions of which vary from person to person. A loss of small airways may contribute to airflow limitation and mucociliary dysfunction, a characteristic feature of the disease. Chronic respiratory symptoms may precede the development of airflow limitation and be associated with acute respiratory events [6]. 
Several systemic inflammatory mediators such as Tumor necrosis factor alpha, interleukins, acute phase protein (C-Reactive Protein $\{\mathrm{CRP}\}$, Lipopolysaccharides Binding Protein $\{\mathrm{LBP}\}$ ) and leucocytes are increased in COPD [7].

CRP is an acute phase protein synthesized in liver in response to acute inflammation. Non hepatic production of CRP by monocyte and lymphocyte has been demonstrated in inflamed lung [8]

Our study aimed to measure CRP level in stable COPD and Acute Exacerbation COPD (AECOPD). It was done at the Chest Department of Agouza Police Hospital. Sixty patients were included in this study, 30 patients with stable COPD and 30 patients with AECOPD, and the results were compared to 10 age matched healthy controls.

In our study, there was no significant difference between stable COPD and AECOPD regarding sex, however there is a significant difference between the two groups regarding age. The mean age for stable group was $52.40 \pm 7.52$ and that of AECOPD was $57.13 \pm 9.45(p=0.036)$. The stable group include 28 males and 2 females while the AECOPD group included 27 males and 3 females and the control group included 9 males and 1 female.

There was a no significant difference between the stable group and the AECOPD group regarding smoking history. All patients of AECOPD were smokers compared to 27 patients of stable COPD group ( $p=0.076)$.

In the current study, the level of CRP was significantly higher in the acute exacerbation cases compared to the stable COPD group and the healthy controls ( $p$-value $<0.0001$ ). Moreover, the level of CRP was significantly higher in the stable COPD group compared to the healthy controls ( $p$-value $<0.0001$ ). This can be explained as follows: In the stable COPD group the CRP level is high due to the present inflammation while in the acute exacerbation group there is superadded infection which raises the CRP level even more.

This is in agreement with the results of the study performed by Prasad et al., [9] in which 100 COPD patients $(80$ stable and 20 in acute exacerbation) and 50 age/sex matched controls were studied and analyzed on the basis of clinical history, CRP levels, BMI, obstructive capacity and exercise capacity to assess their functional status and predict their outcome.

On the other hand, their results showed insignificant difference between stable group and AE-
COPD regarding $\mathrm{FEV}_{1} \%$ and $\mathrm{FEV}_{1} / \mathrm{FVC}$. These results were not consistent with our study.

In the study performed by Kaparianos et al., [10], which compared 162 consecutive male smokers (80 non-COPD smokers marked as controls and 82 COPD smokers) regarding: Age, ABG and pulmonary function test; they found no significant difference between the two groups regarding age, $\mathrm{PH} \& \mathrm{PCO} 2$. This is in agreement with our study.

Additionally, they found significant difference between the two groups regarding the CRP level and $\mathrm{FEV}_{1} \%$ and that was also in agreement with our results.

Moreover, they found no significant difference between the two groups regarding the $\mathrm{PO}_{2}$ and $\mathrm{FEV}_{1} / \mathrm{FVC}$. This was not the case in our study where there was a significant difference regarding the $\mathrm{PO}_{2}$ and the $\mathrm{FEV} / \mathrm{FVC}$ between the stable COPD group and the healthy controls with a $p$ value of $<0.0001$. In our opinion, this can be explained by the fact that the control subjects in the Kaparianos et al., study were all smokers, while those included in ours were non-smokers.

Our study is in agreement with that of Al-Aarag et al., [11] who also found a significant difference between the control group and the COPD group regarding the CRP level.

In a case-control study conducted by Silva et al., [12], CRP levels were determined and pulmonary function tests were performed in a total of 60 stable COPD patients and 30 controls. They found no significant difference between the two groups regarding the CRP level and smoking. This was not the case in our study. These differences can be explained by the fact that they only included patients who had quit smoking in their study.

Regarding the $\mathrm{FEV}_{1} \%$ and the $\mathrm{FEV}_{1} / \mathrm{FVC}$, they found a significant difference between the two studied groups, being in agreement with our results.

In a study performed by (Xiong et al., [13], 368 stable COPD patients $\geq 40$ years old and 296 control subjects $>40$ years old with or without smoking history were enrolled and the results of their routine blood tests were studied to assess their role in predicting the prognosis of COPD. They found no significant difference between the two studied groups in relation to their leucocytic count. This was comparable to the findings of Zhang et al., [14] who enrolled 90 patients with AECOPD who were investigated in the acute phase and reassessed when convalescent (stable COPD), and 90 matched 
controls. Routine blood tests and pulmonary function were assessed. they also found no significant difference between the stable COPD and the control groups in relation to their leucocytic count. This was not the case in our study where we found the leucocytic count to be significantly higher in the stable COPD than the healthy controls with a $p$ value of 0.003 . This difference can be attributed to the comparably small number of subjects in our study.

Zhang et al., [14] also found a significant difference between the stable group and the control group in relation to the CRP level. That is in agreement with our study.

\section{References}

1- VESTBO J., HURD S.S., AGUSTÍ A.G., JONES P.W., VOGELMEIER C., ANZUETO A., BARNES P.J., FABBRI L.M., MARTINEZ F.J., NISHIMURA M. and STOCKLEY R.A.: Global strategy for the diagnosis, management, and prevention of chronic obstructive pulmonary disease: GOLD executive summary. American Journal of Respiratory and Critical Care Medicine, 187 (4): 347-65, 2013.

2- BROEKHUIZEN R., VERNOOY J.H.J., SCHOLS A.M.W.J., DENTENER M.A. and WOUTERS E.F.M.: Leptin as local inflammatory marker in COPD. Respiratory Medicine, 99 (1): 70-4, 2005.

3- YENDE S., WATERER G.W., TOLLEY E.A., NEWMAN A.B., BAUER D.C., TAAFFE D.R., JENSEN R., CRAPO R., RUBIN S., NEVITT M. and SIMONSICK E.M.: Inflammatory markers are associated with ventilatory limitation and muscle dysfunction in obstructive lung disease in well functioning elderly subjects. Thorax, 61 (1): 10-6, 2006.

4- SOLER N.: Systemic markers of exacerbated chronic obstructive pulmonary disease: How they can help with the decision of whether or not to prescribe antibiotics. Archivos de Bronconeumología (English Edition), 44 (11): 581-3, 2008.

5- VOGELMEIER C.F., CRINER G.J., MARTINEZ F.J.,
ANZUETO A., BARNES P.J., BOURBEAU J., CELLI B.R., CHEN R., DECRAMER M., FABBRI L.M. and FRITH P.: Global Strategy for the Diagnosis, Management and Prevention of Chronic Obstructive Lung Disease 2017 Report. Respirology, 22 (3): 575-601, 2017.

6- WOODRUFF P.G., BARR R.G., BLEECKER E., CHRISTENSON S.A., COUPER D., CURTIS J.L., GOUSKOVA N.A., HANSEL N.N., HOFFMAN E.A., KANNER R.E. and KLEERUP E.: Clinical significance of symptoms in smokers with preserved pulmonary function. New England Journal of Medicine, 374 (19): 1811-21, 2016.

7- GAN W.Q., MAN S.F.P., SENTHILSELVAN A. and SIN D.D.: Association between chronic obstructive pulmonary disease and systemic inflammation: A systematic review and a meta-analysis. Thorax, 59 (7): 574-80, 2004.

8- ANDERSON G.P.: COPD, asthma and C-reactive protein. Eur. Respiratory Soc., 27: 874-6, 2006.

9- PRASAD A., SHAH M., BEHAL S., RATHOD M. and PANDEY M.: Prognostic significance of C-Reactive protein and its correlation with predictors of outcome in stable and unstable patients of COPD. Journal of Scientific and Innovative Research, 5 (5): 174-8, 2016.

10- KAPARIANOS A., ARGYROPOULOU E., EFREMIDIS G. and SPIROPOULOS K.: Sex hormone alterations and systemic inflammation in a group of male COPD smokers and their correlation with the +138 ins A/delA endothelin1 gene polymorphism. A case-control study. Eur. Rev. Med. Pharmacol. Sci., 15 (10): 1149-57, 2011.

11- AL-AARAG A.H., ISMAEIL Y.M. and MOHAMMAD A.A.: Study of Serum C-Reactive Protein Level in Patients with COPD. Med. J. Cairo Univ., 80 (2): 163-8, 2012.

12- SILVA D.R., GAZZANA M.B. and KNORST M.M.: Creactive protein levels in stable COPD patients: A casecontrol study. International Journal of Chronic Obstructive Pulmonary Disease, 10: 1719, 2015.

13- XIONG W., XU M., ZHAO Y., WU X., PUDASAINI B. and LIU J.M.: Can we predict the prognosis of COPD with a routine blood test? International Journal of Chronic Obstructive Pulmonary Disease, 12: 615, 2017.

14- ZHANG M., LI Y., ZHANG J., ZHANG Q., YANG X., SHAN H., XIE Y., JIN Q. and FENG X.: Mean platelet volume is elevated in exacerbated and convalescent COPD patients. Clinica Chimica Acta., 451: 227-31, 2015. 


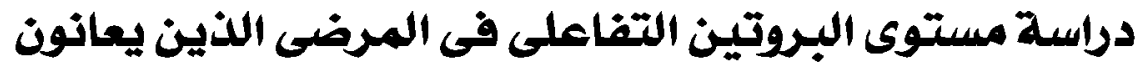

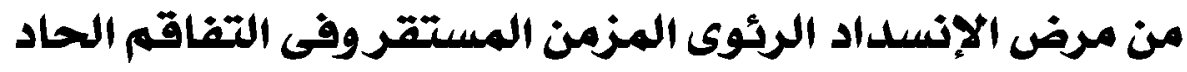

الخلفية: البروتين سى التفاعلى (CRP) هو وسيط إلتهابى يزيد فى المرضى الذين يعانون من مرض الإنسداد الرئوى المزمن (COPD)

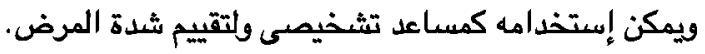
الهدف: دراسة الفرق فى مستوى البروتين سى التفاعلى CRP بين مرضى الإنسداد الرئوى المزمن الهستقر وفى التفاقم الحاد.

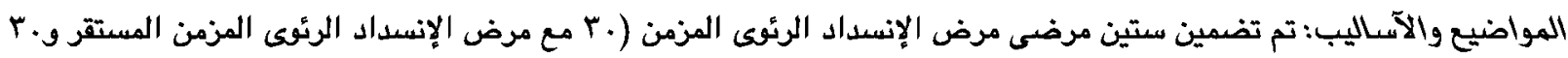

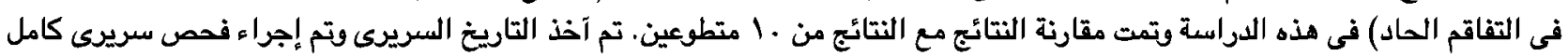

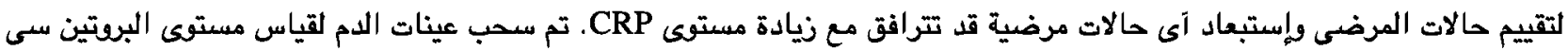
التفاعلى CRP، غازات الدم الشريانية ABG وعد خلايا الدم الآبيض TLC.إختبار وظائف الرئة كما تم.

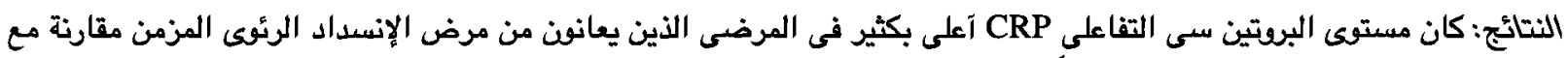

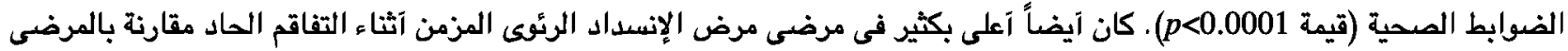

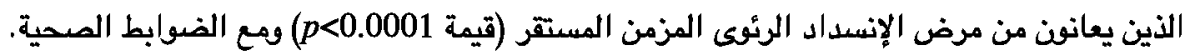

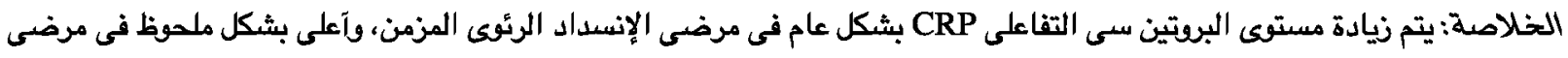

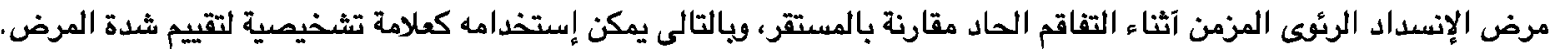

